\title{
Extensive pneumocephalus subsequent to an open skull fracture
}

\author{
Prasad Ellanti, Andrew Moriarity, Nuala McAuley, Thomas McCarthy
}

Department of Orthopaedics, St James's Hospital, Dublin, Ireland

\section{Correspondence to} Andrew Moriarity, andrewmoriarity@gmail.com

Accepted 11 January 2016

CrossMark

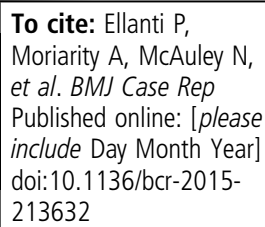

\section{DESCRIPTION}

A 35-year-old man presented to the emergency department, with loss of consciousness subsequent to a fall off a wall of six-foot height. He struck his right occipital area against a short metal spike and was noted to have a small scalp laceration with a discharge of clear fluid consistent with cerebrospinal fluid (CSF). His Glasgow Coma Score (GCS) was 15 on admission. A plain film radiograph of his skull demonstrated pockets of air (figure 1) and an emergent CT scan demonstrated significant pneumocephaly (figure 2A, C, E, G) and a small occipital skull fracture. Other than an improving headache, he was well with a GCS of 15. A neurosurgical opinion was sought and he was managed conservatively with antibiotics and observation. $\mathrm{He}$ was discharged subsequent to a repeat CT scan 7 days later, which showed significant resolution of the pneumocephalus (figure $2 \mathrm{~B}, \mathrm{D}, \mathrm{F}, \mathrm{H}$ ). $\mathrm{He}$ remained asymptomatic at 4-week follow-up. Pneumocephalus is air within the cranial cavity. This can occur as a result of neurosurgery, barotrauma, sepsis, nasopharyngeal tumour invasion and skull fractures. ${ }^{1}$ Symptoms include headache, nausea, vomiting and altered consciousness, but other symptoms may be present depending on the aetiology. Two possible mechanisms are thought to contribute to the formation of a pneumocephalus: first is a valve mechanism where air that has entered the fracture remains trapped due to the fracture or the tissues closing shut; and, second, the leak of CSF causes a negative pressure within the skull cavity, which draws air into it. Pneumocephali can be diagnosed with radiographs but a CT scan is more sensitive. ${ }^{2}$ One study reported up to $9.7 \%$ of head injuries having a pneumocephalus on $\mathrm{CT}^{3} \mathrm{~A}$ large pneumocephalus can develop leading to compression of the brain resulting in a tension pneumocephalus that requires urgent surgical intervention. The majority of post-traumatic pneumocephali

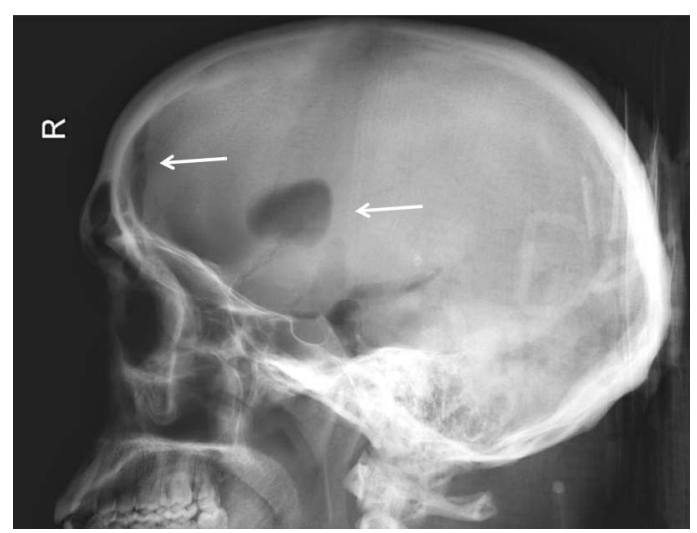

Figure 1 Skull radiograph demonstrating pockets of air

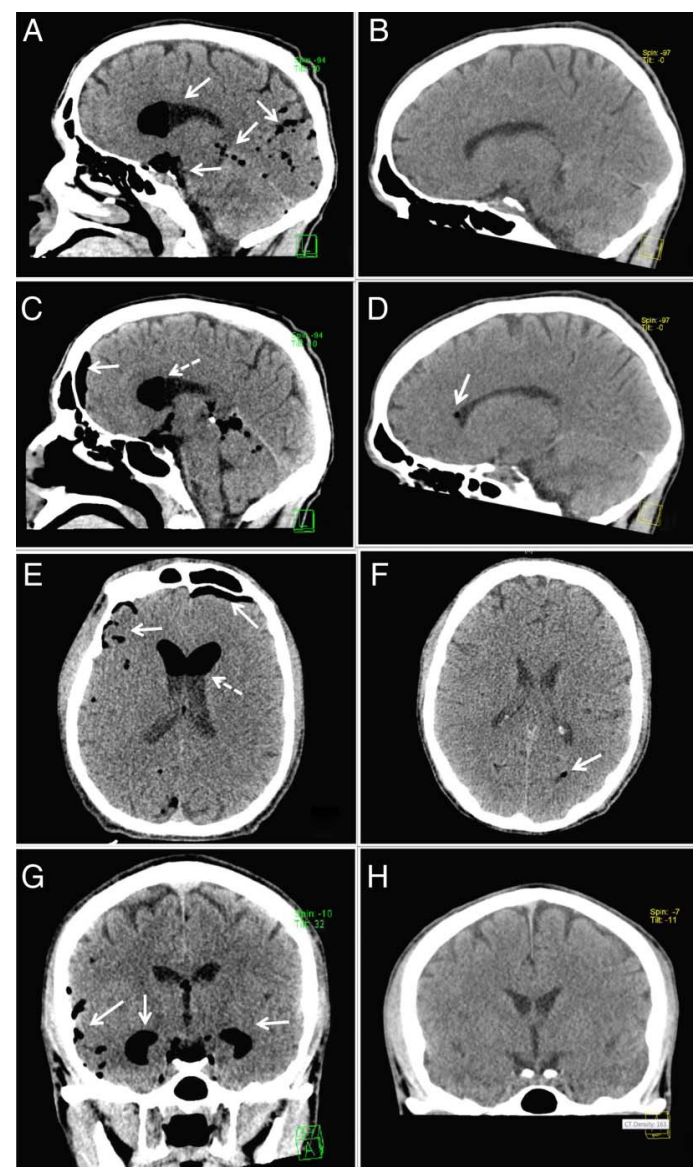

Figure 2 (A, C, E and G) CT scan demonstrating significant pneumocephalus. The solid white arrows point to areas of air within the brain, the dashed white arrows point to air fluid level within the ventricles. $(B, D, F$ and H) Repeat CT scan 7 days postinjury demonstrating significant resolution of the pneumocephalus.

resolve spontaneously, as in our case, and are amenable to conservative treatment with observation, analgaesia and antibiotic prophylaxis.

\section{Learning points}

- Pneumocephalus can be present in patients with minor head trauma and a normal Glasgow Coma Score (GCS).

- Plain films can be useful in the diagnosis of moderate to large pneumocephali, however, CT is the modality of choice.

- The majority of post-traumatic pneumocephali resolve spontaneously and can be managed non-operatively. 
Competing interests None declared.

Patient consent Obtained.

Provenance and peer review Not commissioned; externally peer reviewed.
2 Sharifabad MA, Gianatiempo C, Gharibshahi S. Pneumocephalus: a case report and review of article. Int I Clin Pract 2007;61:74-6.

3 Steudel WI, Hacker H. Prognosis, incidence and management of acute traumatic intracranial pneumocephalus. A retrospective analysis of 49 cases. Acta Neurochir (Wien) 1986;80:93-9.

\section{REFERENCES}

1 Kapoor T, Shetty P. Pneumocephalus. J Emerg Med 2008;35:453-4.

Copyright 2016 BMJ Publishing Group. All rights reserved. For permission to reuse any of this content visit http://group.bmj.com/group/rights-licensing/permissions.

BMJ Case Report Fellows may re-use this article for personal use and teaching without any further permission.

Become a Fellow of BMJ Case Reports today and you can:

- Submit as many cases as you like

- Enjoy fast sympathetic peer review and rapid publication of accepted articles

- Access all the published articles

- Re-use any of the published material for personal use and teaching without further permission

For information on Institutional Fellowships contact consortiasales@bmjgroup.com

Visit casereports.bmj.com for more articles like this and to become a Fellow 